\title{
TRANSFORMATION OF BASIC BELIEFS OF THE PERSONALITY DURING THE LIFE CRISIS PERIOD
}

\section{Tavrovetska N. I.}

\section{INTRODUCTION}

Crisis problematics of the personality is becoming increasingly relevant both for practical psychology and for theoretical search. Human life is full of various situations: not only usual, daily, but also unpredictable, extreme, the general meaning of which is combined in the concept of life crises. They are described in terms of "biographical crises", "problem situations", "life difficulties", "extreme situations", "psychological traumas", etc. Crisis life situations arise in case of difficulties in the system of meaningful relationships of an individual, from inconsistency between the aspirations and possibilities of their realization, from rough disturbance of the usual way of life, from loss of life prospects. Such situations and events place high demands on the adaptive capabilities of a person, as well as on his or her personal potential.

In conditions of painful social, economic, political transformations of Ukrainian society, taking place in recent years, the crisis processes are becoming more widespread and acute. Completeness of the environment with stress factors causes constant emotional stress, which greatly complicates the experience of individual crises.

The importance of life crises is due to the fact that they radically disturb the perception of the external world as a stable, fair and secure. This, in turn, disorganizes the inner world of a person, mostly influencing the apical components of the personality - self-awareness, identity, value orientation, life position and life program. In the event of a negative decision, a life crisis imprints the entire life of a person, causing lack of faith not only in kindness and justice in people, but in themselves, their own strengths and capabilities. In the event of a constructive solution, the crisis, on the contrary, is a powerful source of personal growth, expanding the capabilities of an individual, their confidence and self-efficacy. But in order to adequately overcome the 
inevitable life crises, a person must change their basic beliefs in order to meet a new image of the world.

Today, there is a huge demand for practical psychological support from both individuals and non-governmental organizations. Accordingly, various directions of crisis counseling and traumatic therapy are actively developing; training programs are being implemented for the training of psychologists-associate professionals in crisis counseling, able to work in a stressful environment, to provide support in various types of crisis situations. However, most of these programs are based on Western experience in overcoming crisis situations, which does not always have efficiency in domestic realities (primarily because of a short duration of the period of psychological support and rehabilitation). Consequently, there is an urgent need for the development of theoretical and methodological principles of psychological aid in situations of life crises.

Therefore, the important direction of modern psychology is the study of the characteristics of life crises and the conditions for their overcoming. In our study, we relied on the works of well-known Western scholars (A. Beck, E. Erickson, V. Frankl, H. Shih, I. Yalom, R. Janoff-Bulman, K. Jung) and leading domestic psychologists (F. Vasiliuk, P. Hornostai, V. Horbunova, O. Sannikov, T. Tytarenko and others). Providing psychological aid to a person in a critical life situation is described in detail in the writings of O. Bondarenko, V. Zlyvkov, I. Malkina-Pykh, A. Osypova, M. Padun and A. Kotelnykova, V. Romek, N. Tarabrina. It should be noted that the study of the transformation of a subjective picture of the way of life and the basic beliefs of the personality is significantly complicated by the ethical aspect of the problem, the unpredictability of the emergence of critical situations, as well as the high degree of the individual split growth of the development of the individual in the period of adulthood.

\section{Life crisis as a crucial and life-changing event. Possibilities of cognitive processing of basic beliefs in an acute crisis period}

In psychology, life crises are often understood as the loss of traditional foundations of everyday activities. O. Urbanovych notes that it is a complex transitional state that arises in conditions of impossibility of the established way of human existence, the need to build new vital 
senses, principles and strategies, which is associated with the painful transformation of the "Self".

The life events that cause the crisis put a person in front of the problem which they cannot leave without permission and which cannot be solved in a short time or in a way that is traditional to them. The crisis destroys a daily course of life, habitual representations, and patterns of behavior. Usually this is related to a person's unpleasant revelations (loss, danger, humiliation), which destroys the world of usual realities and the "Self"-image. It provides an uncertain character for a life situation and deprives the opportunity to foresee the future - a person does not know how to live further. It is important that the crisis is global; it affects all aspects of the personality ${ }^{1}$.

An important psychological characteristic of the crisis is a close connection of the subject with the ongoing events, the high degree of significance of the situation for a person. This degree of significance will be the determining factor in whether this event will lead to difficult experiences or will remain unnoticed ${ }^{2}$.

F.Basin highlighted "affecting life situations", those are, situations of emotional stress, which predetermine the emergence of psychological traumas, which affect the most important values of the personality and complicate attempts of psychological protection. This leads to the imbalance of the personality, as well as their adaptability in the external world. A critical component of the situation is determined by the presence of emotional stress, and the degree of its impact on a person by the power of affect and human reactions ${ }^{3}$.

Not only threatening and unfavorable events are difficult to cope with. Positive stressful events (such as a child's birth) cause a wide range of responses, among which there are problems up to serious somatization. However, the evocative potential of negative events (i.e., the potential of causing emotions, from evoke -arouse) prevails over the potential of positive events, since it has adaptive significance for human

${ }^{1}$ Урбанович А. А. Психология управления. Мн. : Харвест, 2003. 640 с.

2 Грызлов С. В. Особенности психологического кризиса как неразрешимой проблемной ситуации и пути коррекции Ин-m психотерапии и клинической психологии. URL: http://www.psyinst.ru/library.php?part=article\&id=1709

3 Бассин Ф. В. «Значащие» переживания и проблема собственно-психологической закономерности. Вопросы психологии. 1972. № 3. С. 105-124. 
survival, maximizes the probability of a quick and effective response to a threat (Tytarenko, 2018).

Significant events instantly cause a complex of person's strong reactions both at the level of the organism and at the level of the personality. Each such positive or negative event affects the personal movement that is reproduced in the reformatting of their own life construction. A person changes the pace of life construction from slow to fast, or vice versa: "He or she begins to accelerate the transformation of the construction site of their own life, modifying, transforming, and sometimes destroying the already constructed". Sometimes they do everything to slow down the changes, save the previously conceived configuration of their own life, even if it becomes completely inappropriate.

It is a crisis situation that helps a person to understand their life plan, makes it possible to see, experience their past, present and future at the same time, to realize their inextricable connection and predicament. T. Tytarenko writes that we are not moving in the way of life according to the logic of the "escalator", and we do not expect that going on a certain step we will continue to go automatically. Our life is always surprises, turns, crossroads which symbolize crisis situations ${ }^{4}$.

The crisis as a discrete moment in the development of an individual occurs when blocking the purposeful life activity of a person or at a sharp change in the status of personal life. Characteristic of the crisis is that a person cannot overcome it by means known from the past experience. Life activity is suspended, as conventional, stereotyped thinking and behavioral programs no longer work, and new ones are not formed yet. This causes a specific acute emotional state ${ }^{5}$.

V. Zlyvkov, S. Lukomska, O. Fedan distinguish the main crises faced by almost every person in their life: a crisis of development (age crises); deprivation crises (a crisis of loss and separation); psychotraumas or traumatic crises; a crisis of relationships caused by getting out of relationships or relationship problems; a crisis of the

4 Титаренко Т. М. Життя як будівельний майданчик: особисті наслідки посттравматичного досвіду. Психологічна допомога особистості в складних обставинах життєдіяльності : зб. доп. всеукр. наук.-практ. сем., м. Чернівці, 18 травня 2018 р. Чернівці : ЧНУ ім. Ю. Федьковича, 2018. С. 6-9.

Доценко В. В. Теоретичні підходи щодо вивчення кризових станів особистості. Вісник Харківського національного ун-ту. Серія «Психологія». 2011. № 937. C. 73-76. 
meaning of life (existential crises); moral and ethical crises (a crisis of spiritual values) ${ }^{6}$.

V. Horbunova notes that a person is exposed to many traumatic factors, more or less threatening, intense and unpredictable throughout their life. In order to recover from stress and return to productive life, one has to cope with emotional experiences and at the same time overcome the anxious patterns of worldview, since the perceived threats make them expect to be similar in the future ${ }^{7}$.

V. Frankl, E.From, I.Yalom and many other authors write about the possibilities of positive changes stimulated by trials of life. Bygone traumas can serve as a catalyst for positive changes, strengthening and deepening relationships, changing the position of life, identifying the strengths of the individual $^{89}$. F. Vasyliuk writes that activity, psyche and consciousness are developed as evolutionary formations in response to the problem and complexity of the external world ${ }^{10}$.

The crisis as an extreme event in life. There are life situations that are so traumatic that require external help, since a person cannot cope with stress themselves (for example, a situation of grief, loss of a loved one or getting out of relationships - when personal resources may not be enough).

M. Ivaniuk notes that the presence of the individual in difficult living conditions that exceed their adaptive potential causes the disturbance of meaningful life interactions of the individual with the world, that is, the experience of alienation. The discrepancy of available possibilities of the individual to the conditions of the situation awakens their fear, insecurity and disability; deep dissatisfaction with their own life, its value deprivation leads to the experience of depression; reduction of self-value leads to loss of authenticity, inability to respect themselves and others; the lack of meaningful expression of will and the

6 Зливков В. Л., Лукомська С. О., Федан О. В. Психодіагностика особистості у кризових життєвих ситуаціях. Київ : Педагогічна думка, 2016. 219 с.

${ }^{7}$ Горбунова В. В. Робота 3 посттравматичним стресовим розладом (ПТСР) у межах когнітивно-поведінкової терапії. Психологічна допомога особистості, щзо переживає наслідки травматичних подій : зб. статей Ін-т соціальної та політичної психології. Київ : Міленіум, 2015. С. 26-35.

${ }^{8}$ Франкл В. Людина в пошуках справжнього сенсу. Психолог у концтаборі. Київ : Клуб Сімейного Дозвілля, 2016. 160 с.

9 Ялом И. Д. Экзистенциальная психотерапия. М. : Класс, 1999. 576 с.

${ }^{10}$ Василюк Ф. Е. Психология переживания (анализ преодоления критических ситуаций) М., 1984. 200 с. 
realization of personal values leads to frustration and loss of meaning of life. Analyses of Ukrainian servicemen-combatants showed the prevalence of the problem of alienation, primarily from society, other people and work (up to $50 \%$ in different groups). The significant difference between active servicemen and veterans is revealed: the latter are more likely to experience the support they can rely on in the external and internal world: the reliability of their attitudes and beliefs, their own feelings, beliefs, attitudes towards themselves and others, the experience of what has already been experienced ${ }^{11}$. In general, the loss of a positive semantic basis in the relationships between a person and the world results in inability to choose and embody new opportunities that can give a sense to life.

In this regard, one should recall the opinion of K. Rogers and other psychologists of the humanistic direction, who consider the flexibility of the value system as a defining feature of a healthy person. A fully functioning person realizes the "Self": they are open to experience, live in the present, trust their intuitive judgments and internal impulses. However, in most psychological sources, the value sphere and basic settings are described as nuclear disposition, a relatively stable personal "core"12.

Psychological approaches explaining the transformation of basic beliefs during the crisis period. The concept of "basic assumptions"/"basic beliefs" is developed at the intersection of cognitive, social, clinical psychology and psychotherapy, which (each of its positions) try to answer the question of how the individual constructs views of the world around and the "Self". The phrase assumptive world - literally "the world of assumptions" is used in Western psychology to refer to a set of basic beliefs that provide a person with support, protection, and a sense of reality (Beder, 2004) ${ }^{13}$. In domestic psychology, the closest to this construct is the concept of "internal picture of the world". In general, basic beliefs can be defined as implicit, global, sustainable representations of the individual about the world and

${ }^{11}$ Іванюк М. О. Екзистенційні мотиви переживання учасниками бойових дій відчуження у складних життєвих ситуаціях. Психологічна допомога особистості в складних обставинах життєдіяльності : зб. доп. всеукр. наук.-практ. сем., м. Чернівці, 18 травня 2018 р. Чернівці : ЧНУ ім. Ю. Федьковича, 2018. С. 40-44.

12 Роджерс К. Р. Взгляд на психотерапию. Становление человека. М. : Прогресс, Универс, 1994. 480 с.

${ }^{13}$ Bede, J. (2004). Loss of assumptive world - How we deal with death and loss. Omega-Journal of Death and Dying, 50 (4), 255-265. 
about themselves, which influence on a person's thinking, emotional states and behavior.

V. Yadov's dispositional model of the personality structure is of particular interest. Dispositions represent a complex of readiness of a person's consciousness and nervous system to act in a certain way. Such positional formations occur each time when meeting a certain need with the corresponding situation of its potential satisfaction. They are organized hierarchically and form four levels. The first level installations regulate direct reactions to an actual substantive situation. The second level regulates the behavior in the usual situations of interaction with the environment. The third level provides for the regulation of the individual's system of actions. A valuable level regulates a person's behavior in significant aspects of social activity, in particular, in problematic, conflict or in situations of moral choice. This model allows asking the question - at what level (or levels) there is an adaptation and transformation of basic beliefs, which accompanies critical periods of life ${ }^{14}$.

From the point of view of existential psychology, a traumatic stressful life event is an experience of acute and sudden collision of person's beliefs with reality, and the course of the crisis will depend on a personality's hardiness. American psychologists S. Cobasa and S. Maddi in their writings note that hardiness consists of three components: engagement, control and risk taking ${ }^{15}$.

According to E. Osin, during the overcoming of life crises, a person experiences a sense of alienation - a disturbance of logical connections in the structure of background knowledge of the personality, which is based on the loss of meaning. The phenomenon of alienation manifests itself as a result of disturbance of the system of links between human life and the world, when they are deprived of a positive meaning for an individual and are not able to act as an energy and logical basis for a fully-fledged action in the world. The result of the impossibility of building their life activity on the basis of internal sense is its

14 Ядов В. А. Саморегуляция и прогнозирование социального поведения личности: Диспозиционная концепция. 2-е расширенное изд. М. : ЦСПиМ, 2013. 376 с.

${ }^{15}$ Kobasa, S. (1979). Stressful life events, personality, and health: An inquiry into hardiness. Journal of Personality and Social Psychology, 37, 1-11.

${ }^{16}$ Maddi, S. (2004). Hardiness: An operationalization of existential courage. Journal of Humanistic Psychology, 44, 279-298. 
construction on other, more primitive principles: biological needs and social norms ${ }^{17}$.

From the point of view of cognitive psychology, the concepts of "cognitive schemes", "constructs", "beliefs", "cognition", by which people structure their own experience and form behavior, are used. According to J. Kelly, the process of human thinking proceeds on the basis of the formation of polar statements (constructs). The desire to avoid uncertainty leads to the choice of the "either-or" principle, and the desire to compensate for the anxiety caused by a basic conflict and the "principle of satisfaction" determine the choice of one or another polarity ${ }^{18}$.

Most fully this process appears in the concept of basic beliefs of R. Janoff-Bullman, that explains how the individual constructs their ideas about the world and the "Self". Basic beliefs are born in childhood and generally provide a sense of security, trust in the world. This is necessary internal support in a changing reality, which promotes the mental stability of a person and their success in life, and is also an important condition for personal development. But the basic beliefs are changed under the influence of mental trauma, because extreme negative experience is contrary to the described concept of life. Its comprehension causes difficult and prolonged psychological problems: an individual faces the horrors of the world, as well as with their own vulnerability and helplessness. Confidence in their own security is an illusion that introduces a person into a state of disintegration. A sense of helplessness, loss of control over one's own life can persist for a long time after the initial symptoms disappear. Accordingly, the process of overcoming the trauma is in restoring the basic beliefs. In case of success, they are transformed and become qualitatively different, which frees a person from the illusion of their own invulnerability ${ }^{19}$.

In domestic psychology in recent years the concept of conscious life construction is becoming rather popular. T. Tytarenko proposes the classification of post-traumatic life construction on the basis of the

${ }^{17}$ Osin, E. (2008). Subjective alienation: Measurement and correlates. International Journal of Psychology, 43, 509.

18 Падун М. А., Котельникова А. В. Психическая травма и картина мира. Теория, эмпирия, практика. М. : Институт психологии РАН, 2012. 133 с.

${ }^{19}$ Janoff-Bulman R. Shattered assumptions: Towards a new psychology of trauma. NY : Oxford University Press, 1992. 256. 
N. Taleb's popular concept of "antifragile"20. Antifragile individuals live easily and feel relatively well in conditions of unpredictability, uncertainty, and chaos, because they are able to modify their own strategies of life construction in accordance with various coincidences both positive and negative. Potentially traumatic situations do not become unequivocally negative events for them, as is the case with fragile individuals; they may not at all get the status of included in the life story of events, remaining unpleasant anecdotes, and may even change the emotional valence, turn into events more positive than negative. The traumatic event is perceived primarily as information that will facilitate further life-style movement. In the history of life of an antifragile person who has survived a crisis or trauma, there is a sense of community, stability, endurance, self-esteem, and optimism. These positive changes contribute to a deeper interpretation of the event, the organic integration of experience, the construction of a more authentic story about yourself. The constant self-education of such a person, the growth of their readiness for change, and a constructive attitude to their own mistakes provide a greater completeness of life and productive interaction with themselves, the world, and other people ${ }^{21}$.

\section{Empirical study of the transformation of basic beliefs in the context of overcoming life crises}

The main task of the empirical study was to find out the peculiarities of the life principles and basic beliefs of the individual, depending on the experience of surviving life crises. To solve this problem, we have developed two author's methods aimed at determining the level and content of autobiographical stress: the method of structured diagnostic interviews (author's development "Significant life events") for obtaining a general picture of the positive and negative events of the autobiography and the closed form "List of stressful events" with the assessment of the significance of their influence on the emotional, cognitive and behavioral levels (author's development). In addition,

${ }^{20}$ Талеб Н. Н. Антихрупкость. Как извлечь выгоду из хаоса. М. : КоЛибри, Азбука-Аттикус, 2016. 768 с.

21 Титаренко Т. М. Життя як будівельний майданчик: особисті наслідки посттравматичного досвіду. Психологічна допомога особистості в складних обставинах життєдіяльності : зб. доп. всеукр. наук.-практ. сем., м. Чернівці, 18 травня 2018 р. Чернівці : ЧНУ ім. Ю. Федьковича, 2018. С. 6-9. 
diagnostic questionnaires were used: the Posttraumatic Cognitions Inventory (PCTI) questionnaire, created by E. Foa ${ }^{22}$ and co-authors in 1999 to assess three types of post-traumatic cognition: negative thoughts about oneself, negative thoughts about the world, self-comdemnation; Post Traumatic Growth Inventory, developed by R. G. Tedeschi, L. G. Calhoun in 1996, adapted by M. Magomed-Eiminov ${ }^{23,24}$, 1998 (Ukrainian adaptation of V. Zlyvkov, 2016) ${ }^{25}$; R. Janoff-Bulman basic beliefs scale, adapted by O. Kravtsova (2000) ${ }^{26}$.

40 people were involved in the research (18 men and 22 women aged 20 to 52 years). The peculiarity of this category of respondents is that they are adults who already have a certain life experience, including the experience of overcoming life difficulties and self-determination.

The content analysis of the "Significant life events" questionnaire and the "List of stressful events" questionnaire allowed to summarize qualitative information (interviews, content and description of events) and convert it into formalized quantitative indicators. The categories of content analysis were: emotional sign of interpretation of a significant event - in the sample three possible variants were found: positive, negative and change of the sign of the event to the opposite in the process of comprehension; the meaning of a significant event; the meaning of the consequences of a significant event - this category was the most diverse and difficult to analyze. The obtained results showed that, in general, $39 \%$ of the described significant biographical events are the most critical situations, that is, those that endanger the health of a person or their relatives, destroy the usual way of life and activity, disturb relationships with relatives, and in general, exceed an adaptive human potential.

With regard to individual indicators, we calculated the ratio of positive and negative events. This ratio accurately reflects the

${ }^{22}$ Foa E. B., Ehlers A., Clark D. M., Tolin D. F. The Posttraumatic Cognitions Inventory (PTCI): Development and validation. Psychological Assessment. 1999. Vol. 11. P. 303-314.

${ }_{23}$ Магомед-Эминов М. Ш. Трансформация личности. М. : Психоаналитическая ассоциация, 1998. 496 с.

${ }^{24}$ Tedeschi R. G., Calhoun L. G. The posttraumatic growth inventory: Measuring the positive legacy of trauma. Journal of Traumatic Stress. 1996. Vol. 9. P. 455-471.

25 Зливков В. Л., Лукомська С. О., Федан О. В. Психодіагностика особистості у кризових життєвих ситуаціях. К. : Педагогічна думка, 2016. 219 с.

${ }^{26}$ Кравцова О. А. Сексуальное насилие как психологическая травма : дис. ... канд. психол. наук. : 19.00.01. Москва, 2000193 с. 
intenseness of the lifestyle with severe and critical events. In addition, it can testify to the general sign of the world perception of a person, their life optimism, pessimism or neutral attitude. Most of the respondents demonstrate a predominantly positive perception of the world. At the same time, for $22.2 \%$ of the sample, the proportion of positive events on the life path is less than half. This is evidence of a really difficult life situation, full of difficulties and obstacles. Individual lists of meaningful events were processed by the method of content analysis. We have identified meaningful units, counted their prevalence and compiled a list of the most significant determinants of events in the life of modern Ukrainians. In individual lists of meaningful events, certain topical themes are singled out - repetitive situations that occur cyclically at different age stages, essentially repeating a certain life scenario of a person. Among such repetitive patterns are: betrayal, insult and neglect, success in an independent goal or life style, interruption of the usual way of life and the development "from the beginning", change of place (study, work, residence), self-sacrifice for the sake of other interests, significant purchases, events from the lives of their own children.

We believe that such cases reflect not only certain well-established ways of behavior, but also the features of a general picture of the world: because of the variety of life events and situations, a person chooses these episodes as significant and important for them. Let us recall that in the narrative theory it is assumed that human life-story is not only an informative text, but also a way of forming the identity of a person, integration of their experience ${ }^{27}$.

If the spectrum of meaningful life events is rather limited (it is easily generalized in content analysis and is already sufficiently fully mentioned in science-based fiction literature), then the spectrum of individual reactions on them is extremely diverse and wide. In the most general terms, the following types of consequences are mentioned in the interview: bright emotional experiences (happiness on the continuum), gaining experience, confirmation of a certain financial or social status, awareness and strengthening of one's own responsibility, the disappearance of the meaning of life (restoration of the meaning of life), the beginning of a new life stage, awareness of one's own adulthood, an

27 Ларіна Т. О. Особистісні стабілізаційні практики життєконструювання: наративний аналіз. Психологічні перспективи. 2014. Вип. 24. С. 184-194. 
important life choice, confirmation of abilities and competences, own "coolness", empowerment, awareness and overcoming fears, confirmation or change of values, the formation of life stereotypes.

It is important that in many cases the emotional sign of the event itself and its subjective significance do not coincide. Often respondents treat objectively negative events as having a positive impact on their lives. For example, a serious illness teaches a person to "appreciate every day of their own life", unfaithfulness of a man becomes the beginning of a successful independent life. Slightly less $(12.2 \%$ of the entire array of observations) are spreading opposite cases - an event that is usually treated as enjoyable, causes anxiety. For example, at the birth of a child, the world is perceptible as a "dangerous place"; at renewal of family or friendly relationships the disappointment appears.

In addition, we have received some interesting observations that allow us to update the idea of the role of critical events in a person's life situation.

Firstly, a number of critical situations have prolonged action and last for years - among them, first and foremost, serious and chronic illnesses (of people themselves or their relatives).

Secondly, a large number of decisive stages and events of life (both positive and negative) are concentrated in the period of childhood - in most cases they make up 20-25\% of the total list. These include, for example, parents' divorce, betrayal of close friends, bright emotional and positive impressions, as well as significant successes - participation and victory in sporting competitions, in student Olympiads. In this case, the remote consequences of critical events are largely determined by the environment, the extent to which a child was generally able to influence the situation, or acted simply as a hostage of difficult circumstances.

Next, we asked the interviewees to choose the most complex and unpleasant - a crisis life event, the impact of which they consider being the most powerful. The general expression of dysfunctional and negative cognitions in a crisis situation is presented in the sample as follows: $88.9 \%$ of respondents have a significant excess of the indicator on the questionnaire of post-traumatic cognition. Influence is expressed in negative thoughts about the world, which seems to be full of danger, people around them are assessed as not worthy of trust that keeps a person in constant tension. 
Table 2.1

Generalized measurement results of post-traumatic cognitions

\begin{tabular}{|l|c|c|c|}
\hline & $\begin{array}{c}\text { Standards } \\
(\mathrm{M} \pm \sigma)\end{array}$ & $\begin{array}{c}\text { Average } \\
\text { sample } \\
\text { tendencies } \\
(\mathrm{M} \pm \sigma)\end{array}$ & $\begin{array}{c}\text { The share of } \\
\text { people with } \\
\text { signs of } \\
\text { traumatism }\end{array}$ \\
\hline $\begin{array}{l}\text { Negative thoughts about } \\
\text { yourself }\end{array}$ & $1,05 \pm 0,63$ & $2,02 \pm 0,31$ & $50 \%$ \\
\hline $\begin{array}{l}\text { Negative thoughts about } \\
\text { the world }\end{array}$ & $2,43 \pm 1,42$ & $4,35 \pm 0,36$ & $100 \%$ \\
\hline Self condemnation & $1,00 \pm 1,02$ & $1,4 \pm 0,86$ & $38,9 \%$ \\
\hline Total score & $49 \pm 23,5$ & $73,3 \pm 20,8$ & $88,9 \%$ \\
\hline
\end{tabular}

With regard to the results obtained, it should be recalled that, according to cognitive theory (A. Beck, J. Kelly), the processing of information is based on basic beliefs and rules embedded in the schemes-cognitive structures that organize experience and behavior. In this case, the disturbance of normal functioning is associated with the "cognitive vulnerability" of the individual. Each person is characterized by a unique vulnerability and sensitivity according to the schemes available to them. In this regard, each of us is prone, to varying degrees, to mental suffering. According to A. Beck, any personality's disorder is associated with a certain basic convictions. For example, the cognitive basis of avoidance disorder is the belief: "I will be hurt"; for paranoid disorder - the belief "People are potential opponents", for narcissistic disorder - "I'm special", for hysterical disorder - "I need to make an impression", etc. Thus, with the help of dysfunctional cognitive schemes, one can construct a cognitive profile of each disorder.

It is believed that the basis of depression is the cognitive triad: negative basic beliefs about the "Self", the world around and a negative view of the future. This determines the prospects for further researches. It is expedient to include methods for identifying life prospects and individual plans to the list of used techniques.

The results of psychological diagnostics showed that, in general, $77.8 \%$ of respondents respond to a complex, critical situation by personal growth traits. They demonstrate a positive attitude to life, easily adapt to change, feel confident in their own capabilities to solve life problems. 
Table 2.2

Generalized results of parameters of post-traumatic growth

\begin{tabular}{|l|c|c|c|}
\hline \multicolumn{1}{|c|}{ Methodology scales } & $\begin{array}{c}\text { Standards } \\
\text { (middle } \\
\text { interval) }\end{array}$ & $\begin{array}{c}\text { Average } \\
\text { sample } \\
\text { tendencies } \\
(\mathrm{M} \pm \sigma)\end{array}$ & $\begin{array}{c}\text { The } \\
\text { share of } \\
\text { people } \\
\text { with } \\
\text { signs of } \\
\text { growth }\end{array}$ \\
\hline Attitude towards other people & $15-24$ & $21,3 \pm 4,56$ & $44,4 \%$ \\
\hline Improved capabilities & $10-15$ & $18,5 \pm 3,12$ & $83,3 \%$ \\
\hline Personal strengths & $8-15$ & $15,3 \pm 2,08$ & $88,8 \%$ \\
\hline Spiritual changes & $4-6$ & $5,2 \pm 3,35$ & $27,7 \%$ \\
\hline Increasing the value of life & $7-11$ & $11,4 \pm 2,16$ & $55,5 \%$ \\
\hline $\begin{array}{l}\text { Index of post traumatic } \\
\text { growth }\end{array}$ & $33-63$ & $70,4 \pm 11,85$ & $77,8 \%$ \\
\hline
\end{tabular}

Note: normative data are given by V. Zlyvkov, S. Lukomskaya, O. Fedan

First and foremost, post-traumatic personal growth refers to manifestations of personal strengths. People become more selfconfident, understands that they can overcome life anxieties, that they are much stronger than they still believed - such answers were received for $88.8 \%$ of the respondents. $83.3 \%$ respondents point to revealing of new improved capabilities in life: after the crisis situation, people have new interests, new attractive lifestyles, unavailable before, are discovered. People confidently declare their capabilities to positively influence life, to change what is possible to change and accept as a gift something that cannot be changed. In addition, $55.5 \%$ of respondents point to an increase in the value of life: life priorities change, as a result of which a person appreciates every day spent and tries to make it more meaningful.

At the same time, the improvement of the attitude towards other people, the efforts to establish open, close and trusting relationships is not so distinct (only $44.4 \%$ of cases). This corresponds to the results of the previous methodology, which testify to negativization of the general picture of the world as a result of a life crisis. For the majority of respondents (66.7\% of cases) high personal growth parameters are combined with the expression of destructive post-traumatic cognitions. 
Consequently, as a result of the experience of a critical event, the general picture of the world is clearly changed in the direction of negativization. But this does not interfere with the manifestations of personal growth, which is manifested in the expansion of capabilities and the strengthening of a personality. We used a correlation analysis to detect statistically significant interrelationships between measured variables. Before that, according to the results of the interviews, the lists of significant life events we calculated the indicator of the intenseness of life by negative events.

Table 2.3

Correlation analysis of data

\begin{tabular}{|c|c|c|c|c|c|}
\hline \multirow[b]{2}{*}{ Diagnostic scales } & \multirow{2}{*}{ 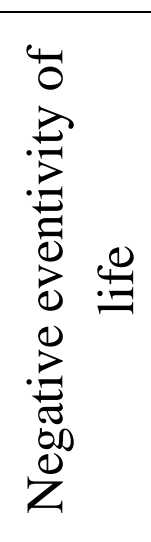 } & \multicolumn{4}{|c|}{$\begin{array}{l}\text { Questionnaire for post- } \\
\text { traumatic cognitions }\end{array}$} \\
\hline & & 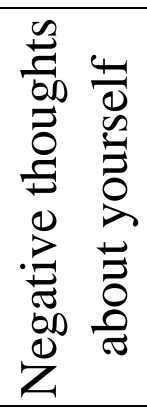 & 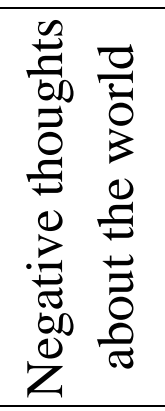 & 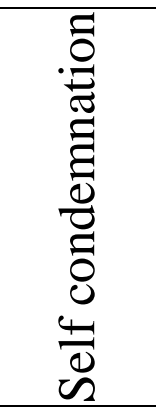 & 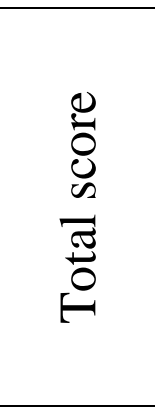 \\
\hline Negative eventivity of life & 1 & 0,288 & 0,171 & 0,604 & 0,343 \\
\hline $\begin{array}{l}\text { Index of post traumatic } \\
\text { growth }\end{array}$ & $-0,502$ & 0,022 & 0,147 & $-0,272$ & $-0,044$ \\
\hline $\begin{array}{l}\text { Attitude towards other } \\
\text { people }\end{array}$ & $-0,588$ & $-0,296$ & $-0,181$ & $-0,509$ & $-0,351$ \\
\hline Improved capabilities & $-0,302$ & 0,292 & 0,394 & 0,002 & 0,234 \\
\hline Personal strengths & 0,132 & 0,564 & $\mathbf{0 , 5 8 7}$ & 0,408 & 0,543 \\
\hline Spiritual changes & $-0,588$ & $-0,296$ & $-0,181$ & $-0,509$ & $-0,356$ \\
\hline Increasing the value of life & 0,286 & 0,588 & $\mathbf{0 , 5 7 5}$ & 0,510 & 0,584 \\
\hline
\end{tabular}

The obtained calculations allow us to draw conclusions about the negative correlation between the index "Negative eventivity of life" and the components of post-traumatic growth $(\mathrm{p} \leq 0.05)$. Consequently, the more human life is full of emotional and negative events, the less they demonstrate the tendency to overcome crisis situations through personal growth (primarily due to reduced attitudes towards other people and 
spiritual changes). At the same time, the tendency to self- condemnation increases significantly $(\mathrm{p} \leq 0.01)$. Perhaps in this there has been noted the depletability of an adaptation resource of the individual. In addition, there are numerous significant correlations between individual posttraumatic personality reactions. Among them, a particular interest is a direct connection of the parameters "Personal strengths" and "Increasing the value of life" with the expressiveness of the formation of destructive cognition. Indicator of self- condemnation negatively correlates with the scales "Attitude towards other people" and "Spiritual changes" $(p \leq 0,05)$. All this requires consideration of changes in the basic settings of a personality as a result of experiencing crisis situations as a single integral system.

The main task of the next stage of the research was to measure the overall level of a biographical stress - the concept that means the total effect of all stress factors that affect a person during a certain period of life, for example, during a year. In this case both positive and negative emotional-loaded life episodes are significant. Investigating the phenomenon of biographical stress, Dr. T. Holmes ${ }^{28}$ and his colleagues constructed a diagnostic scale for commonly used life values, which is actively used in modern psychological practice for screening the level of actual stress of a person. We took this technique as a basis, but greatly supplemented and detailed it.

According to the results of the survey, a wide range of stressful situations, including the most difficult ones, is presented in the life of modern Ukrainians. The highest percentage of prevalence in the sample has the following crisis events: incuring injustice, soreness (repeated throughout life); conflict with nearest and dearest, loss of friends, change of place of residence and the usual way of life. These situations can be considered as normal life trials, which have to be survived almost by every person. In addition, a high level of representation of stressful events in the life that are of an all-embracing nature: natural and technical disasters, repeated economic crises, socio-political upheavals, and military conflict is characteristic for the adult Ukrainians. Interestingly, that people of the same age who were brought up in the same social conditions and experienced the same events in the country,

28 Методика определения стрессоустойчивости и социальной адаптации Холмса и Раге. Эничиклопедии психодиагностики. - URL : http://psylab.info 
when filling out the questionnaire mark them differently. And that is not the case in the selective social memory, but also in the general scheme of the world, as it is perceived by an individual.

Thus, the experience of individual life stressful events is complicated by the global crisis situation, in which one inevitably has to exist, and also by the difficulty of access to external resources of support. It depletes the adaptive reserves of an individual and complicates the experiencing crises.

According to the results of the study, it was found that the following life events, such as divorce or disruption of relationships with loved one; severe illness, trauma causing a fear of death; military conflicts and participation in hostilities; the death of loved one; abortion; failure, failure in meaningful activity, sexual problems or unpleasant sexual experience have and hold the most negative affective potential (i.e the ability to cause strong emotions). Such situations as outstanding personal achievement, success, change of place of residence, promotion in position, marriage, wedding and change of work possess the most positive emotional potential.

A marriage and a birth of children, severe long-term illness (both own and a close person), change in work, failure in significant activities and participation in hostilities strongly influence the behavioral activity of the individual. As to the impact on the thoughts and perceptions of life, the respondents highly evaluated the impact of the same situations, as well as the experience of large financial debts.

Such common factors have already been described in the scientific literature. For example, within the framework of a personal-situational approach, L. Burlachuk and A. Korzhova ${ }^{29}$ distinguish between "strong" and "weak" situations, which differ in expressiveness of reactions of the subjects to one event or another. There are strong negative (death of parents or children) and strong positive (birth of children and grandchildren, recovery, trip to rest, return to work, completing of children's education). In "weak" situations, the role of personal features is great. Allocation of "strong" situations allows predicting reactions to a particular event. The "weakness" of the situation indicates the effectiveness of appeal to the individual in the process of psycho-

${ }^{29}$ Бурлачук Л. Ф., Коржова Е. Ю. Психология жизненных ситуаций : учеб. пособ. М. : Рос. педагогическое агентство, 1998. 263 с. 
correction, the ability to change the system of treatment to a painful situation.

According to the results of the survey, we calculated a number of individual quantitative parameters: stressedness of the last year - the total number of stressed fields over the past year; a biographical stress the total number of stressful events throughout life; a social stress irresistible disturbances of the usual way of life of the entire community (city, region, country); the degree of subjective significance of stressful events at different levels: emotional, cognitive, behavioral. The ratio of these indicators shows an individual style of response to difficult life situations.

We compared these parameters with the results of the psychological diagnosis of basic beliefs of an individual "World Assumptions Scale" (R. Janoff-Bullman). Normally, the scores on all scales should be above the middle, i.e not less than 3.5 points (above 12 points for the total indicator). The following data are obtained in our sample.

Table 2.4

Generalized results of the measurement of basic beliefs

\begin{tabular}{|l|c|c|}
\hline & $\begin{array}{c}\text { Average sample } \\
\text { tendencies } \\
(\mathrm{M} \pm \sigma)\end{array}$ & $\begin{array}{c}\text { The share of people } \\
\text { with a deviation from } \\
\text { the norm } \\
\text { (less than 12 points) }\end{array}$ \\
\hline $\begin{array}{l}\text { 1) benevolence of the } \\
\text { world }\end{array}$ & $16,5 \pm 1,12$ & $7,5 \%$ \\
\hline 2) benevolence of people & $15,7 \pm 1,25$ & $5 \%$ \\
\hline 3) justice of the world & $13,8 \pm 1,35$ & $15 \%$ \\
\hline $\begin{array}{l}\text { 4) controllability of the } \\
\text { world }\end{array}$ & $16,1 \pm 0,81$ & $5 \%$ \\
\hline 5) coincidence of events & $14,5 \pm 2,16$ & $12,5 \%$ \\
\hline 6) value of the "Self" & $17,2 \pm 1,88$ & - \\
\hline 7) degree of self-control & $17,9 \pm 1,62$ & $10 \%$ \\
\hline $\begin{array}{l}\text { 8) degree of success or } \\
\text { luck }\end{array}$ & $15,2 \pm 2,35$ & - \\
\hline
\end{tabular}


From these descriptive statistics, we see that the respondents have mostly positive perception about themselves and the world (we do not exclude that in this case there is an effect of social desirability). Among the individual scales of the questionnaire, the most expressive deviations from the "healthy" system of basic beliefs were found on the scale of "Justice of the world" and "Coincidence of events". Correlation analysis showed a large number of meaningful connections between the saturation of autobiography with stressful events and indicators of basic beliefs. First of all, one should pay attention to the fact that the more stressful events are in a person's life, the lower marks they put to significance of their influence on their own emotions, cognitions and behavior $(p \leq 0.05)$. Hence, a hard life experience causes some tolerance to stressful events - the inevitable daily difficulties and problems do not cause too much emotional reactions (this is possible due to addiction / training and development of tolerance for stress or, visa versa, through the mechanism of psychological protection due to exhaustibility of adaptive resources). According to the results of the correlation analysis, it has been established that the intenseness of life with stressful events (in all aspects) is negatively correlated with the indicators "Benevolence of the world" and "Benevolence of people". Intenseness of life with crisis events negatively affects the basic beliefs about the benevolence of the world. Such a result is quite logical, because the world objectively appears to be a dangerous place for a person, full of anxieties and disappointments. At the same time, intenseness of life with stressful events positively correlates with the basic conviction of controllability of the world. This is especially true for social stress $(\mathrm{p} \leq 0.01)$. Consequently, as a result of the frequent experiences of crises, a person develops a steady conviction that it is possible to avoid misfortunes if a person does not allow mistakes, make efforts for their own protection and avoid troubles. Obviously, there is a security function in it and it actually helps to overcome the difficulties. However, such an attitude can cause increased emotional stress due to constant expectation for troubles. Direct relations between the expression of stressfulness and basic beliefs about the value of the "Self" $(p \leq 0.05)$ have been revealed. Consequently, the experience of solving and surviving the problems forms an attitude towards themselves as a beautiful and worthy person who has nothing to be ashamed of. 
Evaluation of the impact of stressful events on emotions, cognition and behavior demonstrate correlations with all, without exception, basic beliefs of the individual. But the nature of these relationships is different. Direct correlations are observed with respect to the parameters of "benevolence of the world", "benevolence of people" and "degree of self-control". We can interpret this in the following way: a person who believes in the fact that the world as a whole is a good place, people in it are good and ready to help, and they are sufficiently able to control the events of their own life in the face of life difficulties turns out to be very amazed, their vital illusions are destroyed. This, in turn, causes not only painful emotional experiences, but also appropriate alterations of cognitive patterns and behavioral habits. The basic beliefs about the justice of the world (justice, controllability, and the distribution of coincidence events) have negative correlations with the parameters of the subjective significance of stress. The same picture is observed with respect to the values of the "Self" and confidence in own degree of success or luck.

Concerning the obtained empirical results, one should mention the researches of D. Savelyev ${ }^{30}$, who compared the peculiarities of experiencing the crisis of identity in people who have overcome the difficult life situations themselves or with the help of a psychologist. The results showed the expressiveness of intrapersonal and interpersonal conflicts among people who applied for psychological aid. They appreciate themselves relatively well, but they show a distinct disintegration in the areas of work, material security, the state of the inner world, health, family relationships, relationships with society, and in the perception of their own future. Instead, for individuals who deal with their own problems, the parameters of relationships with the others, trust, expected attitude from others, general internality and internality in the field of achievements, failures, family and production relationships, in attitude towards health and illnesses were more expressive. On the basis of these data, it can be assumed that the respondents who applied for psychological aid take less responsibility for the quality of their own lives (external

30 Савельев Д. И. Психологическое содержание кризиса идентичности личности Известия Российского государственного университета им. А.И. Гериена. 2009. № 116. С. 276-283. 
type of control of all scales of the method of the level of "subjective control", except the scale of "internality in the field of interpersonal relations"). In spite of this, they are not ready to build trustful and harmonious relationships, do not trust others, negatively perceive others and expect negative evaluations from them. The obtained results partly confirm the data we received concerning high selfesteem and negative perception of the world around.

Thus, our research helped us to explain the formation of the basic cognitive beliefs that concerns negative perception of the world aroud and intense self-value of people who have high level of a biographical stress.

\section{CONCLUSIONS}

Consequently, complex and crisis challenges from the environment throughout the life of a person are the main reasons of personal movement. Therefore, in the context of practical psychological aid, it is useful to consider the crisis as a certain turning point in human life, when something new is born as a result of suffering and pain. Any crisis is the choice. It is either in protection of the internal picture from any external evidence of its inaccuracy, or in trying to form a new picture of the world. The other way requires the restructuring of the logical structures of consciousness and the reorientation to new life tasks that lead to a change in the nature of activity.

Hence, a difficult life experience causes some tolerance to stressful events (due to the formation of distress tolerance or, vice-versa, through the mechanism of psychological protection and the exhaustibility of adaptive resources). The intenseness of life with crisis events negatively affects the basic beliefs about the benevolence of the world and people and, at the same time, positively correlates with the conviction of controllability of the world around. It has a protective function and contributes to overcoming the difficulties, but causes an increase in emotional stress. The experience in surviving problems generates the value of the "Self". A person who believes in the fact that the world is a good place, people in it are good and ready to help, and they are sufficiently able to control the events of their own life as a result of the collision with life difficulties, suffers from the painful destruction of life illusions. It stimulates appropriate reorganization of cognitive patterns and behavioral habits. 
Since the cognitive possibilities of rethinking during the crisis are reduced, the problem of psychological care should be aimed primarily at reducing the acuity of the emotional experience of the problem, removing a person from the stage of acute stress and restoring the internal resource for constructing new cognitive schemes of the world and their own lives.

Our research has explained the formation of cognitive schemes relating to the negative perception of the world and increased self-value of the people with a high level of a biographical stress. For a practical psychologist it is important to identify the nature of experiencing the crisis life events and help to use these changes as a source of personal growth. An analysis of basic beliefs can significantly expand the understanding of the crisis, achieve greater impact in crisis counseling and crisis therapy.

\section{SUMMARY}

The article deals with theoretical and practical approaches in the study of the basic beliefs of the individual in the context of overcoming life crises. The concept of "basic beliefs" is analyzed from the cognitive, social, existential position. It is noted that a traumatic stressful event is an experience of acute and sudden collision of human beliefs with reality, and the course of the crisis will depend on a person's hardiness, on the level of disturbance of logical connections in the structure of background knowledge of the personality, which is based on the loss of meaning. The level of biographical stress in the life of modern Ukrainians is revealed, which is represented by a wide range of crisis situations, including the most difficult ones.

The research conducted proves that the more human life is full of stressful events, the lower evaluations people put to the significance of their influence on their own emotions, cognition and behavior, and to a lesser extent demonstrates the ability to overcome crises by personal growth. It is concluded that the intenseness of life with crisis events negatively affects the basic beliefs about the benevolence of the world and people and, at the same time, positively correlates with the conviction of controllability of the world around. An empirical analysis of the results helps to explain the formation of basic cognitive beliefs regarding the negative perception of the world and increased self-value of people with a high level of a biographical stress. 


\section{REFERENCES}

1. Бассин Ф. В. «Значащие» переживания и проблема собственно-психологической закономерности. Вопросы психологии. 1972. № 3. C. 105-124.

2. Бурлачук Л. Ф., Коржова Е. Ю. Психология жизненных ситуаций : учеб. пособ. М. : Рос. педагогическое агентство, 1998. $263 \mathrm{c}$.

3. Василюк Ф. Е. Психология переживания (анализ преодоления критических ситуаций) М., 1984. 200 с.

4. Горбунова В. В. Робота 3 посттравматичним стресовим розладом (ПТСР) у межах когнітивно-поведінкової терапії. Психологічна допомога особистості, щзо переживає наслідки травматичних подій : зб. статей Ін-т соціальної та політичної психології. Київ : Міленіум, 2015. С. 26-35.

5. Грызлов С. В. Особенности психологического кризиса как неразрешимой проблемной ситуации и пути коррекции Ин-m психотерапии и клинической психологии. URL: http://www.psyinst.ru/ library.php?part=article\&id $=1709$

6. Доценко В. В. Теоретичні підходи щодо вивчення кризових станів особистості. Вісник Харківського національного ун-ту. Серія «Психологія». 2011. № 937. С. 73-76.

7. Зливков В. Л., Лукомська С. О., Федан О. В. Психодіагностика особистості у кризових життєвих ситуаціях. Київ : Педагогічна думка, 2016. 219 с.

8. Іванюк М. О. Екзистенційні мотиви переживання учасниками бойових дій відчуження у складних життєвих ситуаціях. Психологічна допомога особистості в складних обставинах життєдіяльності : зб. доп. всеукр. наук.-практ. сем., м. Чернівці, 18 травня 2018 р. Чернівці : ЧНУ ім. Ю. Федьковича, 2018. С. 40-44.

9. Кравцова О. А. Сексуальное насилие как психологическая травма : дис. ... канд. психол. наук. : 19.00.01. Москва, 2000193 с.

10. Ларіна Т. О. Особистісні стабілізаційні практики життеконструювання: наративний аналіз. Психологічні перспективи. 2014. Вип. 24. С. 184-194.

11. Магомед-Эминов М. Ш. Трансформация личности. М. : Психоаналитическая ассоциация, 1998. 496 с. 
12. Методика определения стрессоустойчивости и социальной адаптации Холмса и Раге. Энииклопедии психодиагностики. - URL : http://psylab.info

13. Падун М. А., Котельникова А. В. Психическая травма и картина мира. Теория, эмпирия, практика. М. : Институт психологии РАН, 2012. 133 с.

14. Роджерс К. Р. Взгляд на психотерапию. Становление человека. М. : Прогресс, Универс, 1994. 480 с.

15. Савельев Д. И. Психологическое содержание кризиса идентичности личности Известия Российского государственного университета им. А.И. Гериена. 2009. № 116. С. 276-283.

16. Талеб Н. Н. Антихрупкость. Как извлечь выгоду из хаоса. М. : КоЛибри, Азбука-Аттикус, 2016. 768 с.

17. Титаренко Т. М. Життя як будівельний майданчик: особисті наслідки посттравматичного досвіду. Психологічна допомога особистості в складних обставинах життедіяльності : зб. доп. всеукр. наук.-практ. сем., м. Чернівці, 18 травня 2018 р. Чернівці : ЧНУ ім. Ю. Федьковича, 2018. С. 6-9.

18. Урбанович А. А. Психология управления. Мн. : Харвест, 2003. $640 \mathrm{c}$.

19. Франкл В. Людина в пошуках справжнього сенсу. Психолог у концтаборі. Київ : Клуб Сімейного Дозвілля, 2016. 160 с.

20. Ядов В. А. Саморегуляция и прогнозирование социального поведения личности: Диспозиционная концепция. 2-е расширенное изд. М. : ЦСПиМ, 2013. 376 с.

21. Ялом И. Д. Экзистенциальная психотерапия. М. : Класс, $1999.576 \mathrm{c}$.

22. Bede, J. (2004). Loss of assumptive world - How we deal with death and loss. Omega-Journal of Death and Dying, 50 (4), 255-265.

23. Foa E. B., Ehlers A., Clark D. M., Tolin D. F. The Posttraumatic Cognitions Inventory (PTCI): Development and validation. Psychological Assessment. 1999. Vol.11. P. 303-314.

24. Janoff-Bulman R. Shattered assumptions: Towards a new psychology of trauma . NY : Oxford University Press, 1992. 256.

25. Kobasa, S. (1979). Stressful life events, personality, and health: An inquiry into hardiness. Journal of Personality and Social Psychology, 37, 1-11. 
26. Maddi, S. (2004). Hardiness: An operationalization of existential courage. Journal of Humanistic Psychology, 44, 279-298.

27. Osin, E. (2008). Subjective alienation: Measurement and correlates. International Journal of Psychology, 43, 509.

28. Tedeschi R. G., Calhoun L. G. The posttraumatic growth inventory: Measuring the positive legacy of trauma. Journal of Traumatic Stress. 1996. Vol. 9. P. 455-471.

\section{Information about the author:} Tavrovetska N. I.

PhD (Psychology), Assistant Professor, Head of the Department of Practical Psychology Kherson State University 27, Universytetska str., Kherson, 73000, Ukraine 